\title{
Place of death in the Czech Republic and Slovakia: a population based comparative study using death certificates data
}

\author{
Martin Loucka*, Sheila A Payne, Sarah G Brearley and EURO IMPACT
}

\begin{abstract}
Background: Place of death represents an important indicator for end-of-life care policy making and is related to the quality of life of patients and their families. The aim of the paper is to analyse the place of death in the Czech Republic and Slovakia in 2011. Research questions were focused on factors influencing the place of death and specifically the likelihood of dying at home.

Methods: Whole population data from death certificates for all deaths in the Czech Republic and Slovakia in 2011 were used for bivariate and multivariate analyses. Separate analysis using binary logistic regression was conducted for subpopulation of patients who died from chronic conditions.

Results: The majority of population in both countries died in hospitals (58.4\% the Czech Republic, 54.8\% Slovakia), less than one-third died at home. In case of chronic conditions, death at home was significantly associated with underlying cause of death (cancer and heart failure), being male, age (older than 85, Slovakia only) and higher education (the Czech Republic only). Cancer and heart failure patients had higher chances to die at home than other chronic conditions.

Conclusions: Czech and Slovak patients with chronic conditions are more likely to die in hospitals than in some other European Union member countries. This finding should be addressed by policy makers in promoting home hospice care services and education in palliative care for staff in nursing homes and other end-of-life settings.
\end{abstract}

Keywords: Health policy, End-of-life care, Palliative care, Location of death, Eastern Europe

\section{Background}

Death certificates represent a useful monitoring tool for public health policy [1,2]. Choosing the best quality measures for end-of-life care is a very complex issue [3,4] and information about place of death has been suggested to be one of the key indicators [5-7]. Together with research on place of death preferences $[8,9]$, the analysis of actual place of death is essential in planning appropriate end-oflife care policy [10]. Although the relationship between preference for place of death and actual choice is rather complex and influenced by various factors $[11,12]$, dying at home is often cited as the indicator of quality of end-oflife care because home is usually the preferred place for

\footnotetext{
* Correspondence: m.loucka@lancaster.ac.uk

The International Observatory on End-of-Life Care, Division of Health Research, Faculty of Health and Medicine, Lancaster University, Lancaster LA1 $4 Y G, U K$
}

\section{Biomed Central}

most people [13]. Previous studies have also highlighted the association between place of death with health care expenditure [14], the quality of life of dying patients and the bereavement outcomes of their relatives [15].

The modern form of death certificates (List o prohlídce mrtvého) has been collected in the Czech Republic and Slovakia since 1964 [16]. Similar to other European Union countries, it is completed by the attending physician usually at the place of death. It consists of both an administrative and clinical section and is subsequently sent to national statistics offices for further processing. The national statistics offices use parts of death certificates to analyse and publish official mortality statistics. Data about place of death have been included in this official database since 2007 in the Czech Republic and since 2011 in Slovakia.

To our knowledge, this is the first study using the whole population death certificates data from the Czech 
Republic and Slovakia and also from the region of Eastern Europe. The study sought to answer the following research questions:

1) What was the general distribution of cause and place of death in the Czech Republic and Slovakia in 2011?

2) What was the distribution in place of death for deaths caused by chronic conditions in the Czech Republic and Slovakia in 2011?

3) What factors influence the likelihood that a person in the Czech Republic or Slovakia died from a chronic condition at home in 2011?

\section{Methods}

\section{Study design}

Death certificates data for all deaths in the Czech Republic (total population 10,505,445) and Slovakia (total population 5,404,322) in $2011(\mathrm{~N}=154288)$ were obtained from the Institute of Health Information and Statistics of the Czech Republic and the National Health Information Centre of the Ministry of Health of the Slovak Republic. They were received in anonymized form and collated together into one database. As the data were obtained in anonymized form and cannot be tracked back to individuals, ethical approval was not required.

Available variables were country, gender, age, date of death, education (elementary, secondary lower, secondary higher, university), marital status (single, married, divorced, widowed), cause of death (four-figure ICD-10 codes) and place of death. There is not a universally accepted coding system for place of death [1] and as such the information differed between both countries. In the Czech Republic the place of death categories include home, hospital, institutes for long term patients, social care homes, public space, during transportation to hospital and "other (please specify)". In Slovakia, the categories are home, hospital, institutes for long term patients, public space, transport and "other (please specify)". For the purpose of this study the datasets from both countries were merged into one database and categories of place of death were recoded to home, hospital, institutes for long term patients, and other (including all other options). The rationale for this recoding was that homes, hospitals, and institutes for long term patients included most of deaths in both countries $(91 \%$ in $\mathrm{CZ}, 87.8 \%$ in SK) and the other categories are either marginal (public space and transportation with less than $4 \%$ of deaths) or not available from both countries (social care homes, available from CZ only with $5.3 \%$ of deaths).

\section{Statistical analysis}

Descriptive statistics were used to present the basic distributions of variables. Bivariate analysis using $X^{2}$ Pearson tests were calculated in order to assess the associations between place of death and other variables. Separate analysis was conducted for deaths caused by chronic diseases as this sub-sample represents a population with similar endof-life trajectory, potentially eligible for palliative care. We adopted the list of chronic diseases previously used in similar studies [2]. Statistical significance level was set as $\mathrm{p}<.01$ with regard to the large sample size.

Significantly associated variables were later used in a binomial logistic regression model (enter selection procedure) comparing the chance of dying from chronic condition at home and in other settings in each country. The model was checked for multicollinearity and tested by Wald statistic and $\chi^{2}$ Pearson test. In order to obtain a consistent sample suitable for regression modelling only people older than 50 years of age were included $(\mathrm{N}=68799)$, because age is strongly related with cause of death [6]. All analyses were executed in IBM SPSS Statistics version 20.

\section{Results}

\section{General population}

There were 102385 deaths in the Czech Republic (CZ) and 51903 in Slovakia (SK) in 2011. Mode for age of death was 82 in SK and 84 in CZ. The mean age of death was significantly lower in SK than in CZ (71.64 versus 74.07 years, $\mathrm{p}<.001)$. Men in both countries were significantly more likely to die at home than women, odds ratio 1.3 in CZ, 1.05 in SK. Major causes of death were diseases of circulatory system (around 50\%) and neoplasms (around 25\%). Distributions of deaths from specific ICD-10 categories are shown in Table 1.

There was a significant association between place of death and country (Table 2). When the place of death was recoded to binary variable (death at home or not), the odds of dying at home was 1.68 times higher in Slovakia $\left(\chi^{2}(1, \mathrm{~N}=154288)=1769.321, p<.001\right)$.

There was a significant association between place of death and cause of death in both the Czech Republic $\left(\chi^{2}(27, \mathrm{~N}=99938)=9207.730, p<.001\right.$, Cramer's $\left.V=.175\right)$ and Slovakia $\left(\chi^{2}(27, \mathrm{~N}=51903)=6446.631, p<.001\right.$, Cramer's $V=.203)$. The distributions are shown in Table 3.

\section{Subpopulation of deaths from chronic conditions Cause of death}

Slightly less than half of all deaths in CZ and SK in 2011 were caused by chronic conditions with cancer and stroke being the most frequent diagnoses (see Table 4). There was a small significant difference between proportion of deaths by chronic conditions in the Czech Republic and Slovakia $\left(\chi^{2}(1, \mathrm{~N}=151841)=529.452, p<.001\right.$, Cramer's $\left.V=.059\right)$. People in the Czech Republic were 1.28 times more likely to die from chronic conditions than people in Slovakia.

\section{Gender and age}

Slightly more men than women died from chronic conditions in both CZ (50.8\% versus 49.2\%) and SK (54.1\% 
Table 1 Deaths in the Czech Republic and Slovakia in 2011 by ICD-10 categories*

\begin{tabular}{|c|c|c|c|c|}
\hline \multicolumn{2}{|l|}{ ICD-10 category } & \multicolumn{2}{|c|}{ Country } & \multirow[t]{2}{*}{ Total } \\
\hline & & $\mathrm{CZ}$ & SK & \\
\hline \multirow[t]{2}{*}{ I. Certain infectious and parasitic diseases } & $\mathrm{N}$ & 1319 & 414 & 1733 \\
\hline & $\%$ & $1.3 \%$ & $0.8 \%$ & $1.1 \%$ \\
\hline \multirow[t]{2}{*}{ II. Neoplasms } & $N$ & 26166 & 12071 & 38237 \\
\hline & $\%$ & $26.2 \%$ & $23.3 \%$ & $25.2 \%$ \\
\hline \multirow[t]{2}{*}{ IV. Endocrine, nutritional and metabolic diseases } & N & 2634 & 714 & 3348 \\
\hline & $\%$ & $2.6 \%$ & $1.4 \%$ & $2.2 \%$ \\
\hline \multirow[t]{2}{*}{ VI. Diseases of the nervous system } & $\mathrm{N}$ & 2013 & 763 & 2776 \\
\hline & $\%$ & $2.0 \%$ & $1.5 \%$ & $1.8 \%$ \\
\hline \multirow[t]{2}{*}{ IX. Diseases of the circulatory system } & N & 49163 & 27306 & 76469 \\
\hline & $\%$ & $49.2 \%$ & $52.6 \%$ & $50.4 \%$ \\
\hline \multirow[t]{2}{*}{$X$. Diseases of the respiratory system } & $N$ & 5396 & 3269 & 8665 \\
\hline & $\%$ & $5.4 \%$ & $6.3 \%$ & $5.7 \%$ \\
\hline \multirow[t]{2}{*}{ XI. Diseases of the digestive system } & N & 4354 & 2870 & 7224 \\
\hline & $\%$ & $4.4 \%$ & $5.5 \%$ & $4.8 \%$ \\
\hline \multirow[t]{2}{*}{ XIV. Diseases of the genitourinary system } & $N$ & 1166 & 680 & 1846 \\
\hline & $\%$ & $1.2 \%$ & $1.3 \%$ & $1.2 \%$ \\
\hline \multirow[t]{2}{*}{ XIX. Injury, poisoning and certain other consequences of external causes } & $\mathrm{N}$ & 5352 & 2821 & 8173 \\
\hline & $\%$ & $5.4 \%$ & $5.4 \%$ & $5.4 \%$ \\
\hline \multirow[t]{2}{*}{ Other categories ${ }^{a}$} & N & 2375 & 995 & 3370 \\
\hline & $\%$ & $2.4 \%$ & $1.9 \%$ & $2.2 \%$ \\
\hline \multirow[t]{2}{*}{ Total } & $\mathrm{N}$ & 99938 & 51903 & 151841 \\
\hline & $\%$ & $100.0 \%$ & $100.0 \%$ & $100.0 \%$ \\
\hline
\end{tabular}

Missing CZ N = 2447, $1.6 \%$.

*There was a significant association between ICD-10 category and country, tested by $X^{2}$ Pearson test, $\mathrm{p}<.001$.

aIII,V,VII,VIII,XII,XIII,XV-XVIII, each caused less than $1 \%$ of deaths.

versus 45.9\%) in 2011. More than 93\% of deaths from chronic conditions were in people older than 50 years of age and more than $63 \%$ were in people older than 70 years of age (see Table 5). Only in the age group of 51-70 years were more deaths caused by chronic conditions than nonchronic conditions.

\section{Place of death}

Most of the deaths caused by chronic conditions occurred in hospitals (around 63\% in both countries). People in the

Table 2 Place of death in the Czech Republic and Slovakia in 2011*

\begin{tabular}{cccccc}
\hline & & Home & Hospital & Institutes for long term patients & Other \\
\hline CZ & N & 20850 & 59767 & 12488 & 9280 \\
& $\%$ & $20.4 \%$ & $58.4 \%$ & $12.2 \%$ & $9.1 \%$ \\
SK & $N$ & 15565 & 28451 & 1582 & 6305 \\
& $\%$ & $30.0 \%$ & $54.8 \%$ & $3.0 \%$ & $12.1 \%$ \\
\hline
\end{tabular}

*There was a significant association between place of death and country, tested by $\mathrm{x}^{2}$ Pearson test, $\mathrm{p}<.001$.
Czech Republic who died from other conditions were 1.8 times more likely to die at home than people who died from chronic conditions, in Slovakia 1.24 times more (Table 6).

\section{Regression analysis}

Only deaths from chronic conditions in people older than 50 years were included in the regression analysis. Cancer patients in both countries were more likely to die at home than patients dying from other chronic conditions. Only patients with heart failure (OR in Czech Rep 1.249, in Slovakia 1.535) and Parkinson's disease (Slovakia only 2.201) had higher chances of dying at home compared with cancer patients. Women were slightly less likely to die at home in both countries (Czech Rep OR 0.911, $p=.011$, Slovakia 0.879). People who died between the ages of 71-84 years in the Czech Republic were less likely to die at home than younger people (OR 0.849). In Slovakia, people 85 years old and older were most likely to die at home (OR 1.572). There was a contradictory result in the influence of education, when higher education status was associated 
Table 3 Cause of death and place of death in the Czech Republic and Slovakia in 2011*

\begin{tabular}{|c|c|c|c|c|c|c|c|c|c|}
\hline \multirow{3}{*}{ Primary cause of death (ICD-10) } & & \multicolumn{8}{|c|}{ Place of death } \\
\hline & & \multicolumn{2}{|c|}{ Home } & \multicolumn{2}{|c|}{ Hospital } & \multicolumn{2}{|c|}{$\begin{array}{l}\text { Institutes for long } \\
\text { term patients }\end{array}$} & \multicolumn{2}{|c|}{ Other } \\
\hline & & $\mathrm{CZ}$ & SK & $\mathrm{CZ}$ & SK & $\mathrm{CZ}$ & SK & $\mathrm{CZ}$ & SK \\
\hline \multirow[t]{2}{*}{ I. Certain infectious and parasitic diseases } & $\mathrm{N}$ & 32 & 14 & 1186 & 383 & 75 & 2 & 26 & 15 \\
\hline & $\%^{a}$ & $0.2 \%$ & $0.1 \%$ & $2.0 \%$ & $1.3 \%$ & $0.6 \%$ & $.1 \%$ & $0.3 \%$ & $0.2 \%$ \\
\hline \multirow[t]{2}{*}{ II. Neoplasms } & $\mathrm{N}$ & 4391 & 3464 & 16719 & 7596 & 4375 & 337 & 681 & 674 \\
\hline & $\%$ & $21.9 \%$ & $22.3 \%$ & $28.5 \%$ & $26.7 \%$ & $35.8 \%$ & $21.3 \%$ & $7.6 \%$ & $10.7 \%$ \\
\hline \multirow[t]{2}{*}{ IV. Endocrine, nutritional and metabolic diseases } & N & 454 & 184 & 1737 & 452 & 253 & 25 & 190 & 53 \\
\hline & $\%$ & $2.3 \%$ & $1.2 \%$ & $3.0 \%$ & $1.6 \%$ & $2.1 \%$ & $1.6 \%$ & $2.1 \%$ & $0.8 \%$ \\
\hline \multirow[t]{2}{*}{ VI. Diseases of the nervous system } & $\mathrm{N}$ & 273 & 248 & 1030 & 348 & 482 & 49 & 228 & 118 \\
\hline & $\%$ & $1.4 \%$ & $1.6 \%$ & $1.8 \%$ & $1.2 \%$ & $3.9 \%$ & $3.1 \%$ & $2.6 \%$ & $1.9 \%$ \\
\hline \multirow[t]{2}{*}{ IX. Diseases of the circulatory system } & N & 11573 & 9748 & 26695 & 13050 & 5530 & 1008 & 5365 & 3500 \\
\hline & $\%$ & $57.7 \%$ & $62.6 \%$ & $45.4 \%$ & $45.9 \%$ & $45.2 \%$ & $63.7 \%$ & $60.1 \%$ & $55.5 \%$ \\
\hline \multirow[t]{2}{*}{$X$. Diseases of the respiratory system } & $\mathrm{N}$ & 662 & 484 & 3847 & 2479 & 557 & 80 & 330 & 226 \\
\hline & $\%$ & $3.3 \%$ & $3.1 \%$ & $6.5 \%$ & $8.7 \%$ & $4.6 \%$ & $5.1 \%$ & $3.7 \%$ & $3.6 \%$ \\
\hline \multirow[t]{2}{*}{$X I$. Diseases of the digestive system } & $\mathrm{N}$ & 532 & 462 & 3538 & 2287 & 181 & 26 & 103 & 95 \\
\hline & $\%$ & $2.7 \%$ & $3.0 \%$ & $6.0 \%$ & $8.0 \%$ & $1.5 \%$ & $1.6 \%$ & $1.2 \%$ & $1.5 \%$ \\
\hline \multirow[t]{2}{*}{ XIV. Diseases of the genitourinary system } & $\mathrm{N}$ & 75 & 90 & 968 & 549 & 81 & 15 & 42 & 26 \\
\hline & $\%$ & $0.4 \%$ & $0.6 \%$ & $1.6 \%$ & $1.9 \%$ & $0.7 \%$ & $0.9 \%$ & $0.5 \%$ & $0.4 \%$ \\
\hline \multirow{4}{*}{$\begin{array}{l}\text { XIX. Injury, poisoning and certain other consequences } \\
\text { of external causes }\end{array}$} & $\mathrm{N}$ & 1440 & 768 & 1918 & 968 & 287 & 33 & 1707 & 1052 \\
\hline & $\%$ & $7.2 \%$ & $4.9 \%$ & $3.3 \%$ & $3.4 \%$ & $2.3 \%$ & $2.1 \%$ & $19.1 \%$ & $16.7 \%$ \\
\hline & $\mathrm{N}$ & 612 & 103 & 1103 & 339 & 400 & 7 & 260 & 546 \\
\hline & $\%$ & $3.1 \%$ & $0.7 \%$ & $1.9 \%$ & $1.2 \%$ & $3.3 \%$ & $.4 \%$ & $2.9 \%$ & $8.7 \%$ \\
\hline \multirow[t]{2}{*}{ Total } & $N$ & 20044 & 15565 & 58741 & 28451 & 12221 & 1582 & 8932 & 6305 \\
\hline & $\%$ & $100 \%$ & $100 \%$ & $100 \%$ & $100 \%$ & $100 \%$ & $100 \%$ & $100 \%$ & $100 \%$ \\
\hline
\end{tabular}

CZ only: Missing N=2447, 2.4\% (Home 3.9\%; Hospital 1.7\%; Institutes 2.1\%; Other 3.7\%).

*There was a significant association between place of death and ICD-10 category in both countries, tested by $x 2$ Pearson test, $\mathrm{p}<.001$.

${ }^{a}$ column percentages for each country.

${ }^{b}$ III,V,VII,VIII,XII,XIII,XV-XVIII, each caused less than $1 \%$ of deaths.

with higher chance of dying at home in the Czech Republic (OR 1.223) and less chance in Slovakia (OR 0.793). $P$ values, odds ratios and confidence intervals for individual factors are shown in Table 7.

\section{Discussion}

Only $20 \%$ and $30 \%$ of all deaths in the Czech Republic and Slovakia in 2011 occurred at home. This highlights a major discrepancy between actual and preferred place of death as the majority of people in these countries expressed a preference to die at home (78\% in CZ, [17]). This result is similar to other European countries $[6,18]$ and confirms a common trend with more than half of the populations dying in a hospital setting $(58.4 \%$ in $\mathrm{CZ}$, $54.8 \%$ in SK).

Further analysis showed that almost two thirds of patients with chronic conditions died in hospitals in the Czech Republic and Slovakia. This number is considerably higher than in other countries with similar sized populations, such as the Netherlands [2], where only around 30\% of deaths in people with chronic conditions occur in a hospital setting. Regression analysis confirmed that place of death is strongly associated with underlying cause of death with cancer patients being more likely to die at home than patients dying from other chronic conditions.

The results of this study support several trends identified in other countries, such as the discovery that more than half of the population die in hospitals and that men are more likely to die at home than women, probably because they die at a younger age when their wives or partners can help facilitate care at home $[6,10,18,19]$. However, we also found some differences between the Czech Republic and Slovakia and other countries. In the Czech Republic and Slovakia most people who died from chronic conditions in 2011 died in hospitals (around 63\% in both countries). There are several possible explanations for 
Table 4 Deaths caused by chronic conditions in CZ and SK 2011

\begin{tabular}{|c|c|c|c|}
\hline & & & Total $(\mathrm{N}, \%)$ \\
\hline & $\mathrm{CZ}(\mathrm{N}, \%)$ & SK $(\mathrm{N}, \%)$ & \\
\hline Cancer (C00-C97 and D37-D48) & $26101(26.1 \%)$ & $12038(23.2 \%)$ & $38139(25.1 \%)$ \\
\hline Cerebrovascular diseases (stroke) (160-169) & $10244(10.3 \%)$ & $5336(10.3 \%)$ & $15580(10.3 \%)$ \\
\hline Heart failure (150) & $4006(4.0 \%)$ & $1671(3.2 \%)$ & $5677(3.7 \%)$ \\
\hline Chronic liver disease (K70 and K72-K74) & $1899(1.9 \%)$ & $1347(2.6 \%)$ & $3246(2.1 \%)$ \\
\hline Chronic obstructive pulmonary disorders (COPD) (J40-J47) & $2488(2.5 \%)$ & $746(1.4 \%)$ & $3234(2.1 \%)$ \\
\hline Diabetes (E10-E14) & $2237(2.2 \%)$ & $653(1.3 \%)$ & $2890(1.9 \%)$ \\
\hline Dementia (F00-F03 and G30) & $1678(1.7 \%)$ & $226(0.4 \%)$ & $1904(1.3 \%)$ \\
\hline Chronic kidney disease (N03-N04, N11-N13 and N18) & $767(0.8 \%)$ & $488(0.9 \%)$ & $1255(0.8 \%)$ \\
\hline Parkinson's disease (G20-G21) & $210(0.2 \%)$ & $83(0.2 \%)$ & $293(0.2 \%)$ \\
\hline Multiple sclerosis (G35) & $88(0.1 \%)$ & $32(0.1 \%)$ & $120(0.1 \%)$ \\
\hline Spinal muscular atrophy and related disorders (G12) & $84(0.1 \%)$ & $23(<0.0 \%)$ & $107(0.1 \%)$ \\
\hline Neuromuscular disorders (G70-G71) & $31(<0.0 \%)$ & $13(<0.0 \%)$ & $44(<0.0 \%)$ \\
\hline Acquired immunodeficiency syndrome (AIDS) (B20-B24) & $7(<0.0 \%)$ & $1(<0.0 \%)$ & $8(<0.0 \%)$ \\
\hline overall proportion of deaths by chronic conditions ${ }^{\mathrm{b}}$ & $49840(49.9 \%)$ & $22657(43.7 \%)$ & $72497(47.7 \%)$ \\
\hline overall proportion of deaths by non-chronic conditions & $50098(50.1 \%)$ & $29246(56.3 \%)$ & $79344(52.3 \%)$ \\
\hline Total & 99938 (100\%) & $51903(100 \%)$ & $151841(100 \%)$ \\
\hline
\end{tabular}

${ }^{\mathrm{b}}$ There was a significant difference between proportions of deaths from chronic and non-chronic conditions in $\mathrm{CZ}$ and SK, tested by $X^{2}$ Pearson test, $\mathrm{p}<.001$. Missing N = 2447 (CZ only).

this finding. In the Netherlands, where only a third of such patients die in hospitals, nursing home care is developed to a very high level and provides care for similar proportion of dying people as hospitals [2]. In neither the Czech Republic nor Slovakia are such nursing homes available. Care homes for older people or local variations of nursing homes usually do not have a physician on the staff and many GPs do not have enough experience with symptom management at the end of life [20]. When complications occur the patient is most likely to be transported to hospital. Institutes for long term patients, which do have physicians on the staff, are often under such budgetary pressures that they can't afford for example appropriate analgesics (Slama O, unpublished presentation ${ }^{\mathrm{a}}$ ).

Odds of dying at home are increased when home palliative care services are available [13]. There are only few palliative home care services available in the Czech Republic and none in Slovakia [21]. The reason for this might be

Table 5 Gender and age distribution of deaths from chronic and non-chronic conditions*

\begin{tabular}{|c|c|c|c|c|c|}
\hline \multirow[b]{3}{*}{ Age category } & \multicolumn{4}{|c|}{ Death from chronic condition } & \multirow[t]{3}{*}{ Total } \\
\hline & \multicolumn{2}{|c|}{$\mathrm{CZ}(\mathrm{N}, \%)$} & \multicolumn{2}{|c|}{ SK $(\mathrm{N}, \%)$} & \\
\hline & Chronic & Non-chronic & Chronic & Non-chronic & \\
\hline $0-1$ years & $11(<0.1)$ & $274(0.5)$ & $10(<0.1)$ & $315(1.1)$ & 610 \\
\hline $2-18$ years & $45(0.1)$ & $214(0.4)$ & $45(0.2)$ & $196(0.7)$ & 500 \\
\hline $19-50$ years & $2037(4.1)$ & $3171(6.3)$ & $1570(6.9)$ & $2399(8.2)$ & 9177 \\
\hline $51-70$ years & 17245 (34.6) & $11812(23.6)$ & $8813(38.9)$ & $7079(24.2)$ & 44949 \\
\hline 71 and older & $30502(61.2)$ & $34627(69.1)$ & $12219(53.9)$ & $19257(65.8)$ & 96605 \\
\hline Total & $49840(100.0)$ & $50098(100.0)$ & $22657(100.0)$ & $29246(100.0)$ & 151841 \\
\hline \multicolumn{6}{|l|}{ Gender } \\
\hline Male & $25329(50.8)$ & $25148(50.2)$ & $12250(54.1)$ & $14547(49.7)$ & 77274 \\
\hline Female & $24511(49.2)$ & $24950(49.8)$ & $10407(45.9)$ & $14699(50.3)$ & 74567 \\
\hline Total & $49840(100.0)$ & $50098(100.0)$ & $22657(100.0)$ & $29246(100.0)$ & 151841 \\
\hline
\end{tabular}

*There was a significant association between age category and cause of death (chronic condition yes/no) in both CZ and SK, tested by $X 2$ Pearson test, $\mathrm{p}<.001$. In Slovakia, there was a significant difference between gender and cause of death $(p<.001)$. 
Table 6 Place of deaths from chronic conditions ${ }^{a}$

\begin{tabular}{|c|c|c|c|c|c|}
\hline \multirow[t]{3}{*}{ Place of death } & \multicolumn{4}{|c|}{ Deaths caused by chronic conditions } & \multirow[t]{3}{*}{ Total } \\
\hline & \multicolumn{2}{|c|}{ YES } & \multicolumn{2}{|c|}{ NO } & \\
\hline & $\mathrm{CZ}(\mathrm{N}, \%)$ & SK $(\mathrm{N}, \%)$ & $\mathrm{CZ}(\mathrm{N}, \%)$ & SK $(N, \%)$ & \\
\hline Home & $7672(15.4)$ & $6232(27.5)$ & $12372(24.7)$ & $9333(31.9)$ & $35609(23.5)$ \\
\hline Hospital & $31824(63.9)$ & $14096(62.2)$ & $26917(53.7)$ & $14355(49.1)$ & $87192(57.4)$ \\
\hline Long term health care facility & $7811(15.7)$ & 719 (3.2) & $4410(8.8)$ & $863(3.0)$ & $13803(9.1)$ \\
\hline Other & $2533(5.1)$ & $1610(7.1)$ & $6399(12.8)$ & $4695(16.1)$ & $15237(10.0)$ \\
\hline Total & $49840(100.0)$ & $22657(100.0)$ & $50098(100.0)$ & $29246(100.0)$ & $151841(100.0)$ \\
\hline
\end{tabular}

${ }^{a}$ There was a significant association between place of death and cause of death (chronic condition yes/no), tested by $\chi^{2}$ Pearson test, $p<.001$. Missing N = 2447 (CZ only).

Table 7 Factors influencing the likelihood of dying from chronic conditions at home*

\begin{tabular}{|c|c|c|c|c|c|c|c|c|}
\hline & & & & & & & & \\
\hline & $p$ & OR & $95 \%$ & r OR & $p$ & OR & $95 \%$ & r OR \\
\hline & & & Lower & Upper & & & Lower & Upper \\
\hline Chronic condition & & & & & & & & \\
\hline Cancer & & & & & & & & \\
\hline Stroke & $<.001$ & .651 & .591 & .716 & $<.001$ & .666 & .608 & .729 \\
\hline Dementia & $<.001$ & .395 & .307 & .507 & .067 & 1.341 & .980 & 1.834 \\
\hline COPD & .008 & .809 & .692 & .947 & $<.001$ & .466 & .373 & .583 \\
\hline Heart failure & $<.001$ & 1.249 & 1.116 & 1.398 & $<.001$ & 1.535 & 1.353 & 1.743 \\
\hline Diabetes & .122 & 1.126 & .969 & 1.308 & .076 & .826 & .669 & 1.020 \\
\hline Parkinson's disease & .834 & .950 & .587 & 1.537 & .001 & 2.201 & 1.360 & 3.562 \\
\hline Chronic kidney disease & $<.001$ & .406 & .284 & .581 & $<.001$ & .392 & .290 & .530 \\
\hline Chronic liver disease & .001 & .705 & .576 & .863 & $<.001$ & .638 & .531 & .767 \\
\hline Spinal muscular atrophy & .124 & 1.646 & .872 & 3.107 & .583 & .734 & .243 & 2.217 \\
\hline Multiple sclerosis & .509 & 1.283 & .612 & 2.691 & .751 & .849 & .309 & 2.334 \\
\hline Neuromuscular disorders & .473 & .472 & .061 & 3.672 & .547 & .516 & .060 & 4.434 \\
\hline Gender & & & & & & & & \\
\hline Male vs. female & .011 & .911 & .847 & .979 & .001 & .879 & .814 & .949 \\
\hline Marital status & & & & & & & & \\
\hline Single & & & & & & & & \\
\hline Married & .046 & 1.169 & 1.003 & 1.363 & .138 & 1.118 & .965 & 1.295 \\
\hline Divorced & .231 & .898 & .753 & 1.071 & .050 & .826 & .682 & 1.000 \\
\hline Widowed & .761 & .975 & .828 & 1.148 & .736 & 1.027 & .880 & 1.198 \\
\hline Age & & & & & & & & \\
\hline $51-70$ years & & & & & & & & \\
\hline 71-84 years & $<.001$ & .849 & .786 & .918 & .644 & 1.020 & .938 & 1.109 \\
\hline 85 and older & .464 & 1.040 & .937 & 1.153 & $<.001$ & 1.572 & 1.399 & 1.767 \\
\hline Education & & & & & & & & \\
\hline Lower vs. higher education ${ }^{a}$ & $<.001$ & 1.223 & 1.122 & 1.332 & $<.001$ & .793 & .729 & .862 \\
\hline
\end{tabular}

*Binary logistic regression (enter method), sample limited to deaths from chronic conditions ( $\mathrm{N}=68779$ ) and age of 51 and older. ${ }^{a}$ Missing data on education status CZ 18939 (39.7\%), SK 4463 (21.2\%), treated by listwise deletion method. 
the fact that palliative home care is still not recognized in the health care insurance law and hence the palliative home care services can't access the governmental health care budget. Legislative issues are main barriers in the further development in both countries, with long term care (including hospice care) being especially challenging area where two sectors, health and social care, are involved and coordination of their policies is difficult [22-24]. The housing situation in the Czech Republic and Slovakia is also an important factor which influences the potential care for a dying relative at home. Typical home environments currently available are either two bedroom flat in cities or larger family houses in the countryside which means that when children want to provide care for their elderly parents they have to struggle either with space limitations or availability of support services which are rarely provided in rural areas [24].

There was a contradictory effect of education found in the selected countries. In the Czech Republic, people with higher education were more likely to die from chronic conditions at home (OR 1.223) while in Slovakia this was less likely (OR 0.793). In other countries the effect between greater education and chance of dying at home is usually positive $[6,10,25]$. Possible explanation for the difference in Slovakia might be the trend of massive urbanization in 1970's and 1980's with higher educated people typically moving into small flats and consequently being less likely to access and provide informal care at their homes. However, recent trends show that older people with university education tend to move out of cities [26], so this association has to be further explored.

This study also has its limitations. Firstly, not all variables, relevant to predicting place of death were available $[1,25]$, for example socio-economic status or level of urbanization. Problems with cause of death coding in death certificates is another well-known issue $[27,28]$ and has been reported also from both selected countries $[29,30]$. A specific complication is the coding of place of death. Apart from lacking an universally accepted coding system [1] the practice of completing this question in forms is not unified. One example of confused practice is when death in social care home is coded as death at home. This situation sometimes happens when the patient has the address of the care home registered as his or her home address. It is not known how often it is, but bias of up to several percentages is possible in the Czech Republic [31]. In Slovakia, this category is not available at all. Similar confusion can occur in coding deaths in institutes for long term patients, which are sometimes mixed with acute hospitals, especially when it was only a long term care ward within a larger hospital. Palliative care units or hospices are not included in either of Czech and Slovak certificates and the coding of hospice deaths is also not clear as hospices can be recognized either as social care homes or "other".

\section{Conclusions}

Analysis of Czech and Slovak death certificates data pointed out several trends previously identified in other countries. More than half of the population dies in hospitals, although the preferred place of death is home for most people. Patients with cancer or heart failure have better chances to die at home than patients dying from other chronic conditions. Apart from cause of death, other sociodemographic variables like gender, age or education influence the place of death. Czech and Slovak patients who died from chronic conditions were more likely to die in hospital setting than patients in other countries. This finding should be taken into account by policy makers and potential changes in health care services delivery suggested, for example with regards of end-of-life care education for general practitioners or the role of nursing homes. Support for palliative care home teams could also improve the likelihood to balance the preferred and actual place of death. However, more research is needed to understand what are the motives for place of death preferences, what conditions at home would really meet people's expectations, as well as to explore the complex system of influencing factors in more detail.

\section{Endnote}

aslama O: Improving Access to Pain Medicines: the example of the Czech Republic. Presentation during 13th World Congress of the European Association for Palliative Care; Prague; 1st June, 2013.

\section{Abbreviations}

CZ: The Czech Republic; SK: Slovakia; Cl: Confidence interval; OR: Odds ratio; ICD-10: International classification of diseases, 10th edition.

\section{Competing interests}

The authors declared that they have no competing interests.

\section{Authors' contributions}

ML obtained the data and performed the analysis. The manuscript was drafted by ML and approved by SB and SP. All three authors read and approved the final manuscript.

\section{Acknowledgements}

We thank Dr Sarka Dankova from the Institute of Health Information and Statistics of the Czech Republic and Dr Anna Barakova from the National Health Information Centre of the Ministry of Health of the Slovak Republic for their support with obtaining the data. We also thank the members of the EURO IMPACT consortium for their support and collaboration. The members are Van den Block Lieve ${ }^{\text {a }}$, Meeussen Koen ${ }^{a}$, Brearley Sarah ${ }^{\mathrm{e}}$, Caraceni Augusto ${ }^{9}$, Cohen Joachim ${ }^{a}$, Costantini Massimo ${ }^{h}$, Francke Anneke ${ }^{b}$ Harding Richard ${ }^{c, d}$, Higginson Irene $J^{c, d}$, Kaasa Stein ${ }^{f}$, Linden Karen ${ }^{k}$ Miccinesi Guido ', Onwuteaka-Philipsen Bregje ${ }^{b}$, Pardon Koen ${ }^{a}$, Pasman Roeline $^{b}$, Pautex Sophie ${ }^{j}$, Payne Sheila ${ }^{e}$, Deliens Luc ${ }^{a, b}$.

This work was supported by the EURO IMPACT project (FP7/2007-2013, grant agreement number 264697). EURO IMPACT, European Intersectorial and Multidisciplinary Palliative Care Research Training, is funded by the European Union Seventh Framework Programme. EURO IMPACT aims to develop a multidisciplinary, multi-professional and inter-sectorial educational and research training framework for palliative care research in Europe. EURO IMPACT is coordinated by Prof Luc Deliens and Prof Lieve Van den Block of the End-of-Life Care Research Group, Ghent University \& Vrije Universiteit Brussel, Brussels, Belgium ${ }^{a}$. Other partners are: VU University Medical Center, EMGO 
Institute for health and care research, Amsterdam, the Netherlands ' ${ }^{b}$; King's College London, Cicely Saunders Institute, London ', Cicely Saunders International, London ${ }^{d}$, and International Observatory on End-of-Life Care, Lancaster University, Lancaster, United Kingdom e; Norwegian University of Science and Technology ${ }^{f}$, and EAPC Research Network ${ }^{9}$, Trondheim, Norway; Regional Palliative Care Network, IRCCS AOU San Martino-IST, Genoa ${ }^{\text {h }}$, and Cancer Research and Prevention Institute, Florence, Italy ; EUGMS European Union Geriatric Medicine Society, Geneva, Switzerland ${ }^{\text {'; }}$ Springer Science and Business Media, Houten, the Netherlands ${ }^{k}$.

Received: 22 July 2013 Accepted: 14 March 2014

Published: 20 March 2014

\section{References}

1. Cohen J, Bilsen J, Miccinesi G, Lofmark R, Addington-Hall J, Kaasa S, Norup M, van der Wal G, Deliens L: Using death certificate data to study place of death in 9 European countries: opportunities and weaknesses. BMC Public Health 2007, 7:283.

2. van der Velden $L F J$, Francke AL, Hingstman L, Willems DL: Dying from cancer or other chronic diseases in the Netherlands: ten-year trends derived from death certificate data. BMC Palliat Care 2009, 8:4.

3. De Lima L, Wenk R, Krakauer E, Ferris F, Bennett M, Murray S, Bruera E, Radbruch L: Global framework for noncommunicable diseases: how can we monitor palliative care? J Palliat Med 2013, 16:226-229.

4. Payne $S$, Leget C, Peruselli C, Radbruch L: Quality indicators for palliative care: debates and dilemmas. Palliat Med 2012, 26:679-680

5. Casarett DJ, Teno J, Higginson I: How should nations measure the quality of end-of-life care for older adults? Recommendations for an international minimum data set. J Am Geriatr Soc 2006, 54:1765-1771.

6. Cohen J, Bilsen J, Hooft P, Deboosere P, Wal G, Deliens L: Dying at home or in an institution: using death certificates to explore the factors associated with place of death. Health Policy 2006, 78:319-329.

7. Houttekier D, Cohen J, Surkyn J, Deliens L: Study of recent and future trends in place of death in Belgium using death certificate data: a shift from hospitals to care homes. BMC Public Health 2011, 11:228.

8. Gomes B, Calanzani N, Gysels M, Hall S, Higginson I: Heterogeneity and changes in preferences for dying at home: a systematic review. BMC Palliat Care 2013, 12:7.

9. Wilson DM, Cohen J, Deliens L, Hewitt JA, Houttekier D: The preferred place of last days: results of a representative population-based public survey. J Palliat Med 2013, 16:502-508.

10. Cohen J, Houttekier D, Onwuteaka-Philipsen B, Miccinesi G, Addington-Hall J, Kaasa S, Bilsen J, Deliens L: Which patients with cancer Die at home? A study of six european countries using death certificate data. J Clin Oncol 2010, 28:2267-2273.

11. Macleod U: Place of death: is home always best? Br J Hosp Med 2011, 72:441-443

12. Campbell ML: Should we be asking about preferred place for dying care? J Palliat Med 2013, 16:462-462.

13. Higginson IJ, Sarmento VP, Calanzani N, Benalia H, Gomes B: Dying at home - is it better: a narrative appraisal of the state of the science. Palliat Med 2013

14. Reich O, Signorell A, Busato A: Place of death and health care utilization for people in the last 6 months of life in Switzerland: a retrospective analysis using administrative data. BMC Health Serv Res 2013, 13:116.

15. Wright AA, Keating NL, Balboni TA, Matulonis UA, Block SD, Prigerson HG: Place of death: correlations with quality of life of patients with cancer and predictors of bereaved caregivers' mental health. J Clin Oncol 2010, 28:4457-4464

16. UZIS CR: Jak správně postupovat prì vyplňování listu o prohlidce mrtvého (LPM): stručný privodce [How to complete the death certificate: a quick guide]. Praha: Institute of Health Information and Statistics of the Czech Republic; 2006.

17. STEM/MARK: Umírání a péče o nevyléčitelně nemocné: Dying and Care for Patients with Incurable Diseases. Praha: Cesta Domü; 2011.

18. Broad J, Gott M, Kim H, Boyd M, Chen H, Connolly M: Where do people die? An international comparison of the percentage of deaths occurring in hospital and residential aged care settings in 45 populations, using published and available statistics. Int J Public Health 2013, 58:257-267.

19. Seale C: Changing patterns of death and dying. Soc Sci Med 2000, 51:917-930
20. Kalvach Z, Čeledová L, Holmerová I, Jirák R, Zavázalová H, Wija P: Křehký Pacient a Primárni Péče. Grada: Praha; 2011.

21. Centeno C, Lynch T, Donea O, Rocafort J, Clark D: EAPC Atlas of Palliative Care in Europe 2013. Fullth edition. Milan: EAPC Press; 2013.

22. Repková K (Ed): Dlhodobá Starostlivost' o Staršcich Ludí na Slovensku a v Európe (3): Správa, Riadenie a Financovanie. Bratislava: Inštitút pre výskum práce a rodiny; 2011

23. Radvansky M, Palenik V: The Long-Term Care System for the Elderly in Slovakia, ANCIEN research project report; 2010. http://www.ceps.eu/book/long-termcare-system-elderly-slovakia.

24. Bodnárová B: Legislatínne Zabezpečenie Rozsahu a Prístupu k Službám Dlhodobej Starostlivosti o Stanj́ch a Chorých Ludí. Stredisko pre štúdium práce a rodiny: Bratislava; 2004.

25. Gomes B, Higginson IJ: Factors influencing death at home in terminally ill patients with cancer: systematic review. BMJ: Br Med J 2006, 332:515-518.

26. Šprocha B: Vnútorná migrácia podla najvyššieho dokončeného vzdelania na Slovensku. Prognostické práce 2011, 3:213-246.

27. Drummond MB, Wise RA, John M, T Zvarich M, McGarvey LP: Accuracy of death certificates in COPD: analysis from the TORCH trial. COPD: J Chron Obstruct Pulmon Dis 2010, 7:179-185.

28. Cambridge B, Cina SJ: The accuracy of death certificate completion in a suburban community. Am J Forensic Med Pathol 2010, 31:232-235. 210.1097/PAF.1090b1013e3181e1095e1090e1092.

29. Baráková A: Kvalita listov o prehliadke mítveho: Súčasný stav, nové možnosti. Med Pract 2011, 6(7):18-19.

30. Muž́k J, Abrahámová J, Dušek L: Stav a Kvalita Hlášení dat o Mortalitě v Národním Onkologickém Registru ČR. In Proceedings of the 37th Oncological Days in Brno: 18-19 April 2013; Brno. Edited by Svoboda M, Slaby O. Brno: Masarykưv onkologický ústav; 2013:43.

31. Cesta domů: Umírání a Paliativní Péče v ČR (Situace, Reflexe, Vyhlídky) [Dying and Palliative Care in the Czech Republic (Situation, Reflection, Future)]. Praha: Cesta domu; 2004

\section{doi:10.1186/1472-684X-13-13}

Cite this article as: Loucka et al:: Place of death in the Czech Republic and Slovakia: a population based comparative study using death certificates data. BMC Palliative Care 2014 13:13.

\section{Submit your next manuscript to BioMed Central and take full advantage of:}

- Convenient online submission

- Thorough peer review

- No space constraints or color figure charges

- Immediate publication on acceptance

- Inclusion in PubMed, CAS, Scopus and Google Scholar

- Research which is freely available for redistribution

Submit your manuscript at www.biomedcentral.com/submit
C Biomed Central 